Dialectic Volume III, Issue I: Visual Essay with Accompanying Prose

\title{
Processing the Pandemic
}

MEAGHAN A. DEE ${ }^{1}$

1. Virginia Tech, School of Visual Arts, Blacksburg, Virginia, USA.

SUGgested CitATION: Dee, M.A., "Processing the Pandemic." Dialectic, 3.1 (2021): pgs. 84-96.

Published by the AIGA Design Educators Community (DEC) and Michigan Publishing.

DOI: http://doi.org/10.3998/dialectic.14932326.0003.104

STABLE URL: http://hdl.handle.net/2027/spo.14932326.0003.104 


\section{Processing the Pandemic}

MEAGHAN A. DEE

\section{Prose Accompaniment}

As we emerge from the global pandemic, our society will need to find ways to process our collective trauma. Creating this visual essay was my way to start unpacking my lived experience of it. Additionally, my dear friend, Blythe Terrell (Supervising Editor of the podcast Science Vs), generously allowed me to

Lutz, E., Aufrichtig, A., Smart, C., Sun, A., Harris, R., and Gianordoli, G., "See Covid-19 Risk in Your County and a Guide for Daily Life Near You," New York Times, 28 March, 2021. Online. Available at: https://www. nytimes.com/interactive/2021/us/covid-risk-map.html (Accessed March 29, 2021).

\section{2}

Ivory, D., Smith, M., Lee, J., Walker, A., Gamio, L., Watkins, D., Hassan, A., Allen, J., Lemonides, A., Bao, B., Brown, E., Burr, A., Cahalan, S., Craig, M., De Jesus, Y., Dupre, B., Guggenheim, B., Harvey, B., Higgins, L., Lim, A., Matthews, A., Moffat-Mowatt, J., Pope, L., Queen,

C., Rodriguez, N., Ruderman, J., Saldanha, A., Thorp, B., White, K.,

Wong, B., and Yoon, J., "See How the Vaccine Rollout Is Going in Your County and State," New York Times, 29 March, 2021. Online. Available at: https://www.nytimes.com/interactive/2020/us/covid-19-vaccine-doses. html (Accessed March 29, 2021). incorporate some pages from her pandemic journal into my collages. Her words reminded me of how I'd felt during the different phases of the year.

While the pandemic is far from being over (as of this writing on March 29, 2021, "a majority of United States counties, residents were at a high risk or higher for contracting COVID-19" "), vaccine distribution is underway (with $29 \%$ of the U.S. population having received at least one dose ${ }^{2}$ ). I recently received my first dose of the Moderna vaccine, and for that I am immensely grateful. Yet where I thought I would feel joy and lightness, instead I feel a weight. Perhaps in my relief, my body let me feel more of the heaviness of the pandemic - the parts it knew I couldn't handle before.

Additionally, this past year was not only about the virus and the millions of lives (and livelihoods) lost world-wide. In the United States, a social justice movement and political division defined 2020. As designers, we know that the messages we create and put out into the world are a part of the collective zeitgeist. The words we choose and the words we use matter. We must do our part to stop hateful rhetoric and its effects - and we must also know when to listen and when to make space. Designers should bring such considerations into their client work but also recognize the benefits of maintaining the sanctity of their personal creative practice. I often process my 
thoughts by engaging in the act of making. Designing is a way for me to slow down, to process, and to clarify ideas. My visual essay strives to capture how 2020 felt to me, and to provide me with a place for reflection.

I chose to abruptly transition from the analog collage I had planned to a highly graphical, digital zoom composition to embody how sudden it felt, as a design educator, to transition from a face-to-face to an online teaching modality. In March of 2020, my university went on spring break, and we never came back. In the middle of our break, administrators made the call to immediately shift our classes online. I had never taught an online class before and had one-week to convert the content of all of my courses so that my students could still gain essential knowledge and skills from them. Daycare and K-12 schools closed. Friends and colleagues with children not only had to re-adapt their work routines, but they also lost all childcare support.

As I write this in March of 2021, most of our classes are still online or hybrid. I always loved teaching. I felt like being a design educator was one of the best jobs a person could have. Yet a year into online teaching in the middle of a pandemic, I am exhausted. I am incredibly lucky to have my job, my health, and my home, and yet, in spite of my extremely fortunate circumstances, I am overwhelmed.

Teaching can be a performative act, yet face-to-face teaching was a communal experience. We shared our energy, ideas, books, and materials. We had chance encounters and serendipitous moments of inspiration. While I'm getting the hang of facilitating online teaching, I'm still unsure about what role I play in the evolving lives of my students. I've had students lose their parents, grandparents, and pets. They share their computers with younger siblings, since they too are having to "learn online." Their internet connections come and go. They are tired. Their mental health is suffering. Dozens have had COVID-19, and many were hit harder than they expected to be. BIPOC students are dealing with the "pandemic within the pandemic" of the all-too-variedand-numerous effects of racism, and AAPI students worried about the safety of their relatives and the challenges inherent in having to internalize the hate they were and still are witnessing.

Berry, A. and Acayo Laker, P., "The Value of Design Education: During a Time of Online Teaching." YouTube, uploaded by the AIGA Design Educators Community, 21 May. 2020, https://www. youtube.com/ watch?v=7m5eAM8wLPs\&t $=50 \mathrm{~s}$
In May of 2020, fellow design educators Anne Berry and Penina Acayo Laker hosted a virtual (zoom) roundtable on The Value of Design Education, ${ }^{3}$ during which they asked, "What value do we provide as design educators?" Upon the conclusion of this, they (along with assistance from the national steering committee of the AIGA Design Educators Community) 
4

AIGA Educators, "Value Design

Education Pledge." AIGA Design

Educators Community, 20 August 2020, https://educators.aiga.org/valuedesigneducation (Accessed August 9, 2021). created the "Value Design Education Pledge." "I have reflected many times since the facilitation of this virtual roundtable on what I offer as a teacher and how to find value in it amid a global crisis. When the pandemic first began, it felt like a short-term survival - like all we needed to do was get through a few weeks. So, I hunkered down - but when I realized we were going to have to ensure this for a long while, I wanted to find a way to create meaningful experiences that allowed me to process and learn from my immersion in it. This visual essay is a part of my attempt to glean and decipher meaning from what has been a tremendously difficult year.

\section{References}

AIGA Educators, "Value Design Education Pledge.” AIGA Design Educators Community, 20 August 2020, https://educators.aiga.org/valuedesigneducation (Accessed August 9, 2021).

Berry, A. and Acayo Laker, P., "The Value of Design Education: During a Time of Online Teaching." YouTube, uploaded by the AIGA Design Educators Community, 21 May. 2020, https://www.youtube.com/ watch?v=7m5eAM8wLPs\&t=50s

Ivory, D., Smith, M., Lee, J., Walker, A., Gamio, L., Watkins, D., Hassan, A., Allen, J., Lemonides, A., Bao, B., Brown, E., Burr, A., Cahalan, S., Craig, M., De Jesus, Y., Dupre, B., Guggenheim, B., Harvey, B., Higgins, L., Lim, A., Matthews, A., Moffat-Mowatt, J., Pope, L., Queen, C., Rodriguez, N., Ruderman, J., Saldanha, A., Thorp, B., White, K., Wong, B., and Yoon, J., "See How the Vaccine Rollout Is Going in Your County and State," New York Times, 29 March, 2021. Online. Available at: https://www.nytimes.com/interactive/2020/us/covid-19-vaccinedoses.html (Accessed March 29, 2021).

Lutz, E., Aufrichtig, A., Smart, C., Sun, A., Harris, R., and Gianordoli, G., "See Covid-19 Risk in Your County and a Guide for Daily Life Near You," New York Times, 28 March, 2021. Online. Available at: https://www.nytimes.com/interactive/2021/us/covid-risk-map.html (Accessed March 29, 2021). 


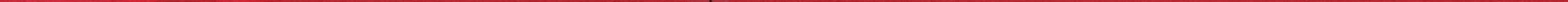


$(5, b 1+4=$

ata 35

1.t

$4+56$

ani

1.

Mi?

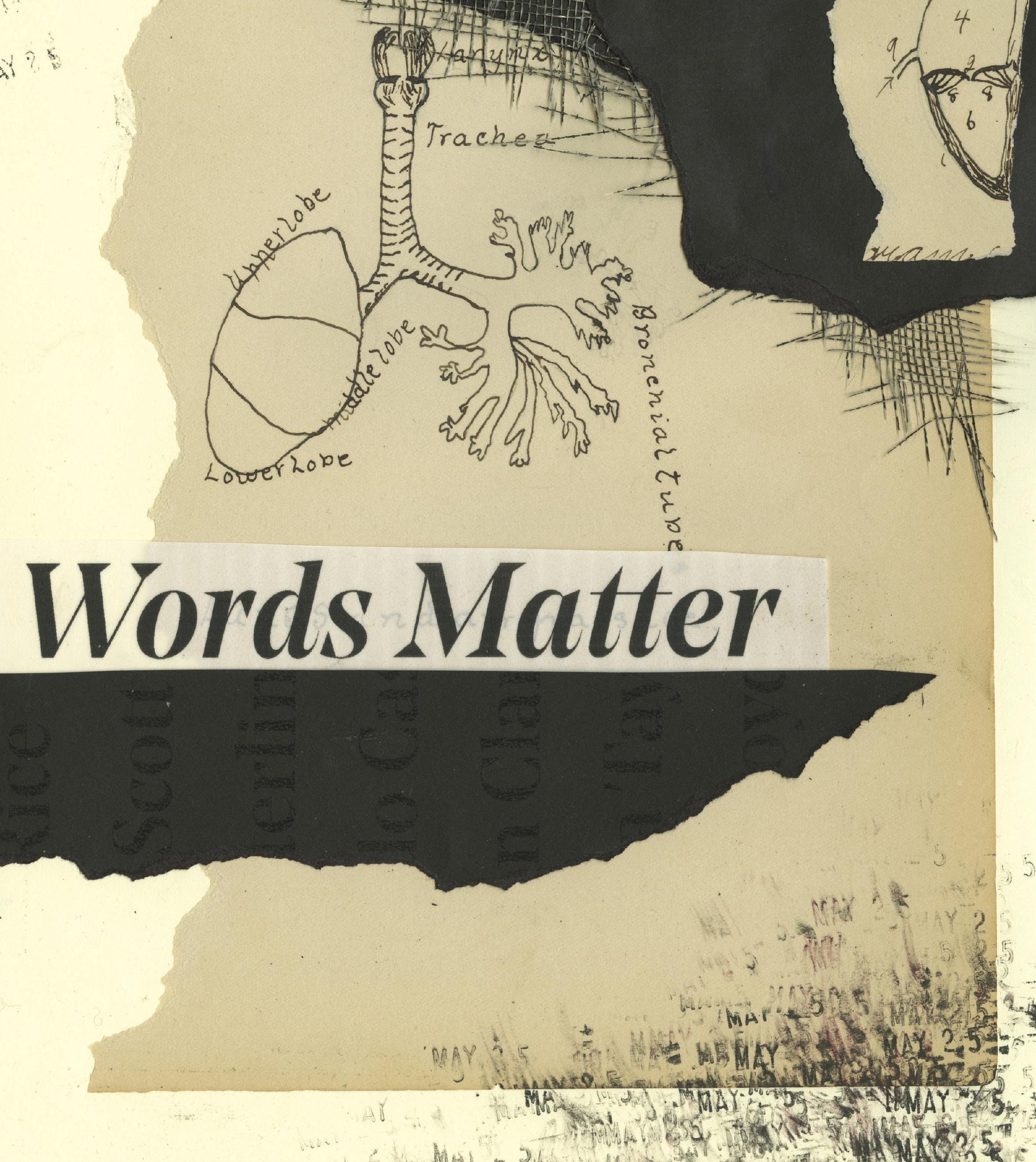




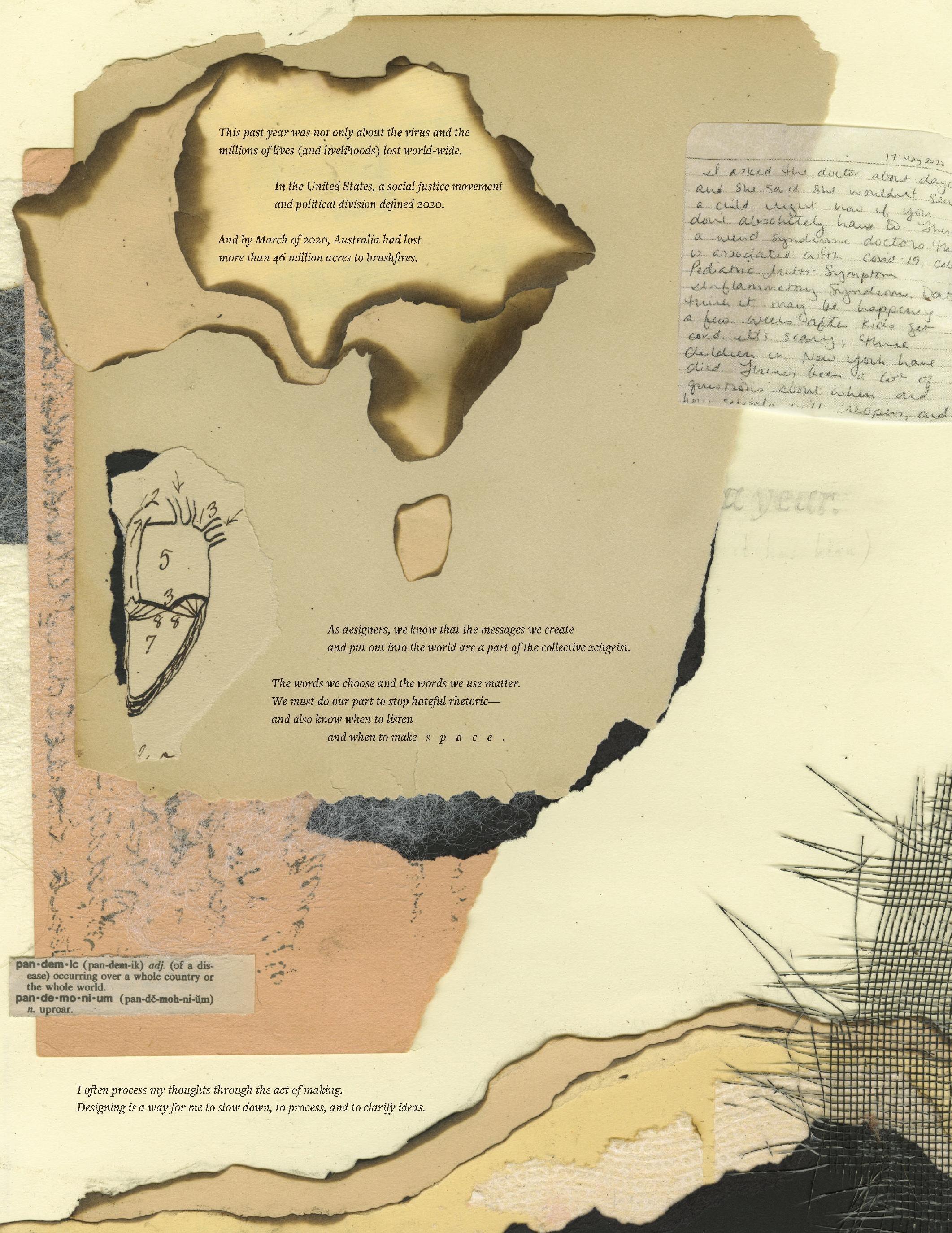




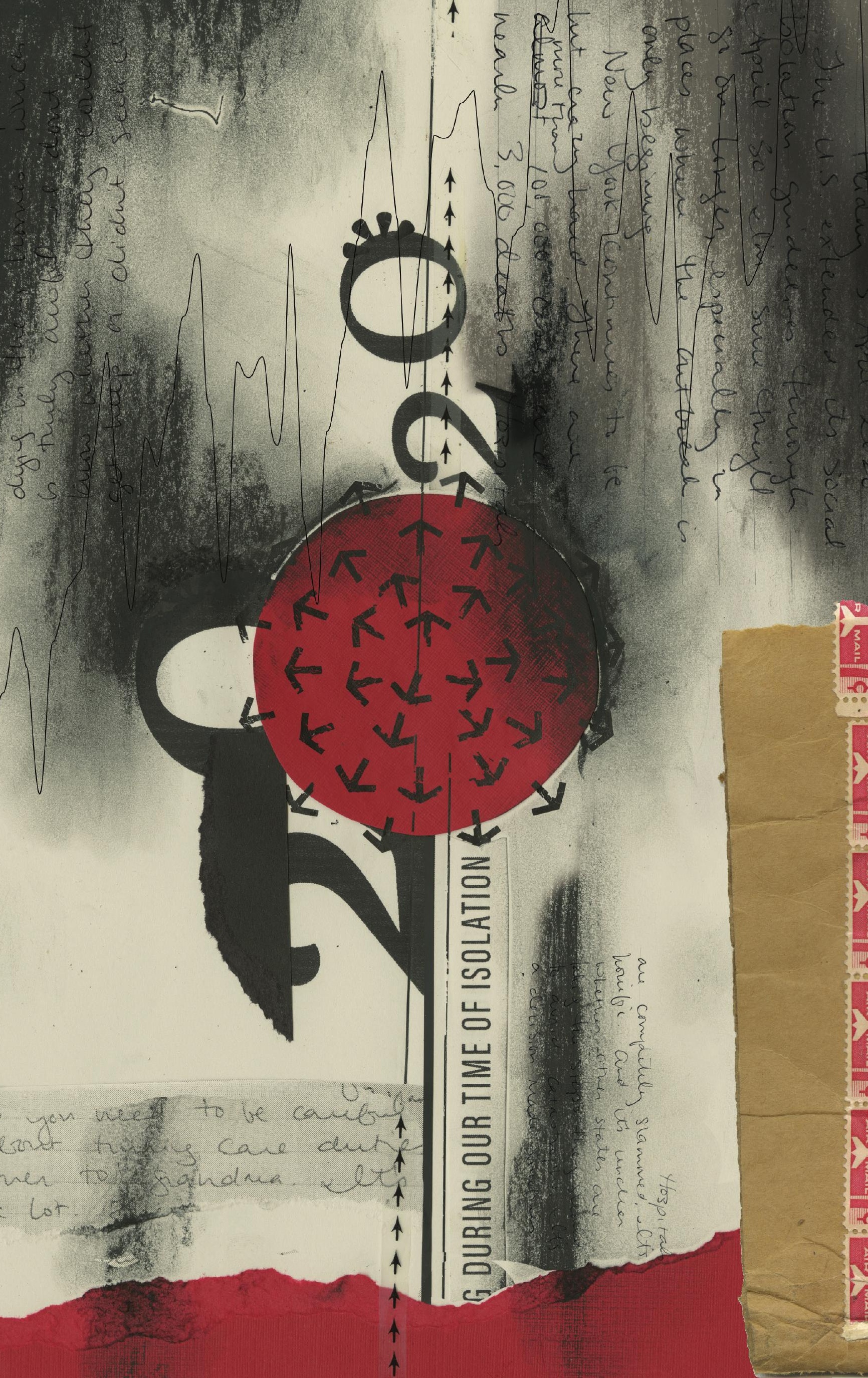


We are living through a particularly peculiar and overwhelming time.
Million of prope have los wa jor elts catastrop Jothin whe thin has emen ingwhere, reely - wi nand to ovestzle ses a

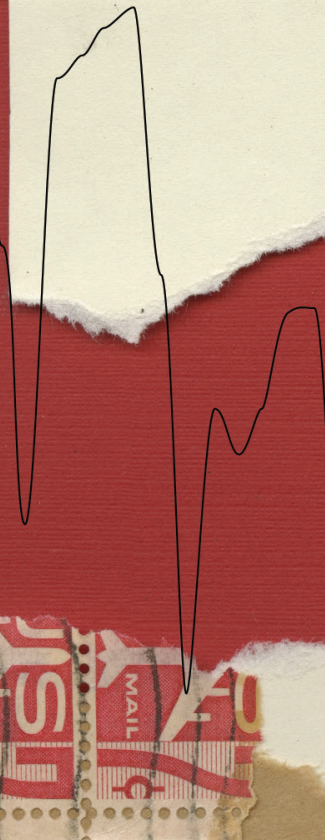

$=2$ deact:

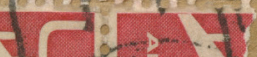

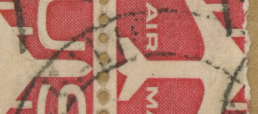
(4I) (ing

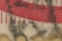
$\frac{1}{0}$ oopopes $2=$ II. A. rentury the ริ $\frac{2}{7}=1$ $3 \frac{3}{3} 4=1$

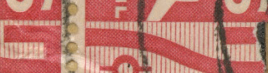
cosese (1)

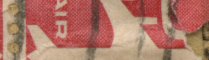
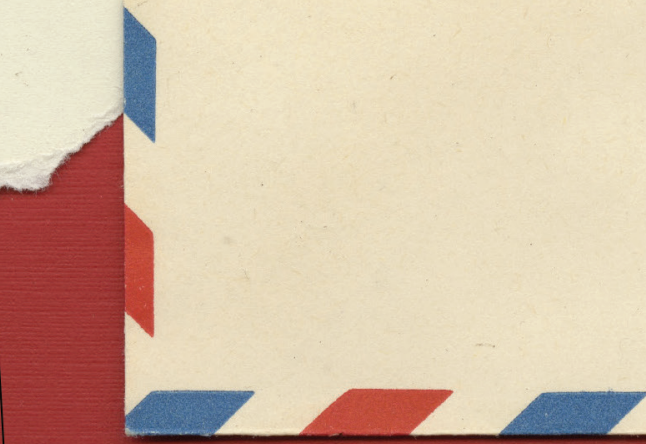

We all felt so much loss this past year-

Loss for the life we had and

the loved ones we couldn't spend time withso moments of connection, joy, and love took on a new meaning for me.

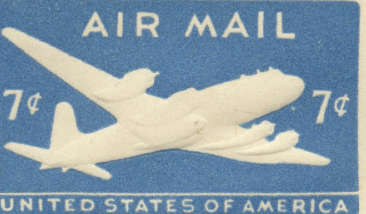

UNITEO STATES OF AMERICA 


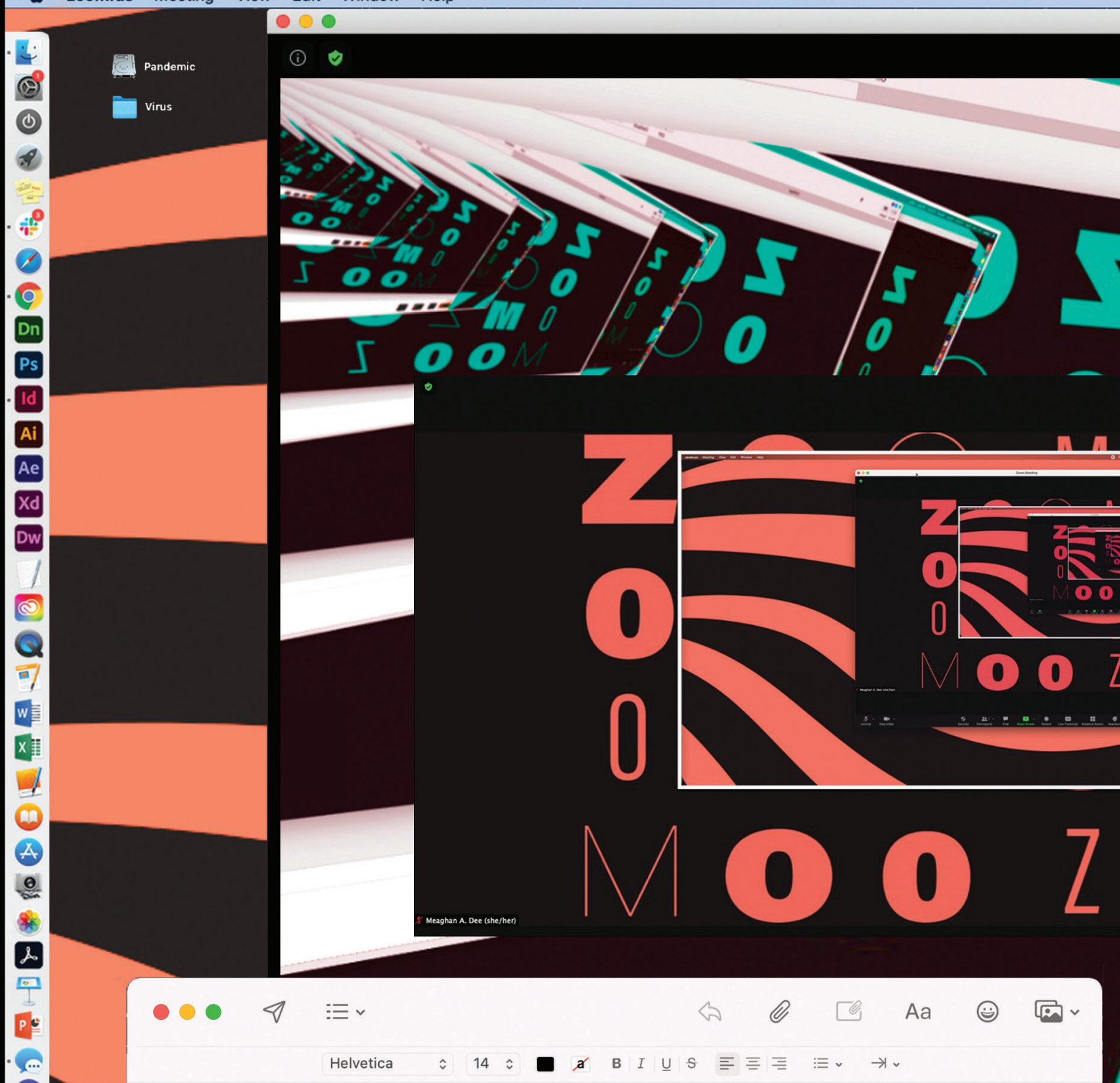

To: Design Educators

Cc: Designers Students

Subject: Teaching during COVID-19

In March of 2020, my university went on spring break, and we never came back. In the middle of our break, administrators made the call to immediately shift our classes online. I had never taught an online class before and had one-week to convert my courses. One of my classes was Packaging, where l'd always emphasized the importance of physically constructing designs and exploring material usage. Additionally, most of my students were seniors about to graduate, several of whom had job offers rescinded, due to the pandemic. Daycare and $\mathrm{K}-12$ schools closed. Friends and colleagues with children not only had to re-adapt their work routines, but they also lost all childcare support.

As I write this in March of 2021, most of our classes are still online or hybrid. I always loved teaching. I felt like being a design educator was one of the best jobs a person could have. Yet a year into online teaching in the middle of a pandemic, I am exhausted. I am incredibly lucky to have my job, my health, and my home, and yet, in spite of my extremely fortunate circumstances, I am overwhelmed.

Teaching can be a performative act, yet face-to-face teaching was a communal experience. We shared our energy, ideas, books, and materials. We had chance encounters and serendipitous moments of inspiration. While I'm getting the hang of the online teaching of design (and ZoomSlackCanvasMiroCreativeCritiqueFigmaAdobeEmailMessagingPadletGoogle), I'm still unsure what role I play in the lives of my students. I've had students lose their parents, grandparents, and pets. They share their computers with younger siblings, since they too are online learning. Their internet connections come and go. They are tired. Their mental health is suffering. Dozens have had COVID (and for each case, we must submit a form to the University) and many were hit harder than they expected. BIPOC students are dealing with the "pandemic within the pandemic" of racism, and AAPI students worried about the safety of their relatives and internalizing the hate they are witnessing.

My "job" this semester is to teach Advanced Typography and a Design Elective-but what is my role? 


\begin{tabular}{|c|c|c|c|}
\hline - & Lot Number & & or Clinic Site \\
\hline $\begin{array}{l}1^{\text {st }} \text { Dose } \\
\text { COVID-19 }\end{array}$ & $\begin{array}{l}\text { moderna } \\
\text { O47A21A }\end{array}$ & $\frac{3}{m m} / \frac{18}{d d} / \frac{21}{y y}$ & 6303 \\
\hline $\begin{array}{l}2^{\text {nd }} \text { Dose } \\
\text { COVID-19 }\end{array}$ & 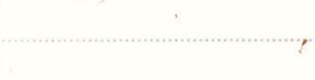 & $\overline{m m}^{\prime} \frac{}{d d} \frac{}{y y}$ & \\
\hline & & 11 & \\
\hline
\end{tabular}
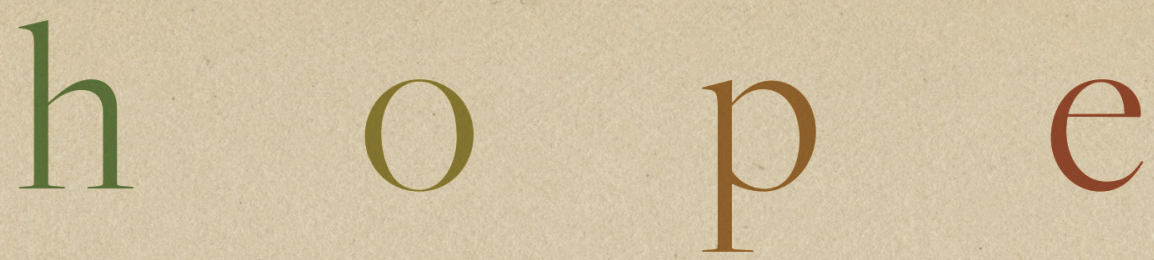

On my drive home,

after receiving my first vaccine,

I saw this rainbow
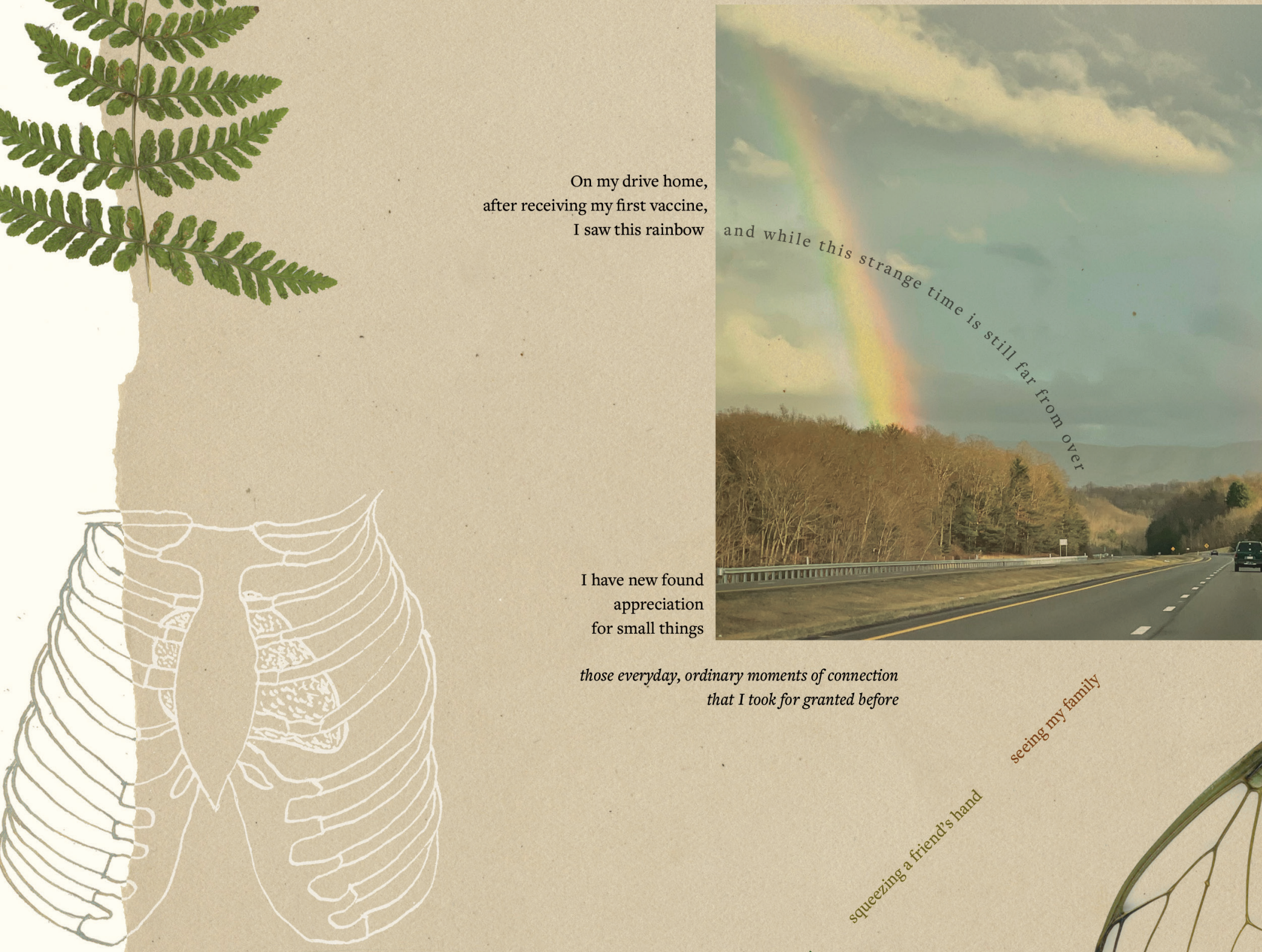

those everyday, ordinary moments of connection that I took for granted before

bad got his fuat Vaccibe dose a weeh ago, and Nom got hen

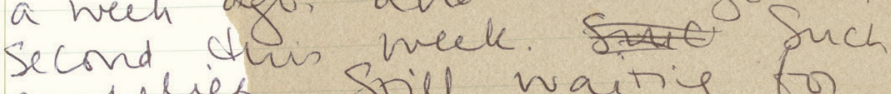
a velief lisibilitu and supplig so he ear ger ows cel wetpe it happerrs 


\section{Biography}

Meaghan Dee is both a practicing graphic designer and a design educator. Currently, she is an Associate Professor of Graphic Design and a Fellow at the Institute of Creativity, Arts, and Technology at Virginia Tech in Blacksburg, Virginia, USA. This summer she ended a seven-year term as Chair of Graphic Design at Virginia Tech and completed a two-year position as Co-Chair of the AIGA Design Educators Community (AIGA DEC) Executive Board. She received her Bachelors' of Fine Arts from the University of Illinois with a focus in Graphic Design, and a Masters' of Fine Arts from Virginia Commonwealth University, with a focus in visual communication design. She specializes in engaging in and examining design and systems thinking, typography, branding, user-experience design, cross-media design, packaging, and editorial design. She's also experimented with many different materials and engaged in a wide variety of creative methods, such as taking her typographic studies into the realms of motion design, AR, and processing. Regardless of the final output, she emphasizes core values, process, and design thinking.

Her work can be seen at meaghand.com. 